\title{
As vozes de dentro da poesia cabralina
}

\author{
The voices from within Cabral's poetry
}

Olliver Mariano Rosa ${ }^{1}$

RESUMO

Neste artigo, tratamos da relação entre a performance vocal e a poesia de João Cabral de Melo Neto. A obra desse poeta é normalmente dividida em duas vertentes: uma de poesia reflexiva, destinada à leitura individual, e outra, de poesia comunicativa, afeita à leitura em voz alta. Reconsideramos essa separação com base na reflexão sobre as possibilidades de comunicação do texto poético por meio de sua execução vocal, ou vocalização. Para isso, discutimos, primeiramente, a configuração das vozes nas publicações que compõem a coletânea Morte e vida severina e outros poemas em voz alta. Depois, distinguindo o caráter exterior dessas vozes, buscamos identificar elementos para percepção e análise da voz que se manifesta na poesia cabralina como virtualidade, constituída pela materialidade sonora e pela subjetividade poética. Fazemos isso com poemas do livro Museu de tudo. Em conclusão, assinalamos que o caráter comunicativo do poema de João Cabral encontra campos de ação mais amplos quando é deslocado para o âmbito performativo da vocalização.

Palavras-chave: João Cabral de Melo Neto; Vocalização de poesia; Museu de tudo.

\section{ABSTRACT}

In this paper, we search the relationship between vocal performance and João Cabral de Melo Neto's poetry. The work of this poet is usually divided into two strands: one of reflective poetry, intended for individual reading, and the other, of communicative poetry, used for reading aloud. We reconsider this separation based on a reflection on the communication possibilities of the poetic text through its vocal execution or its vocalization. For this, we first discuss the configuration of voices in the publications that make up the collection Morte e Vida Severina e outros poemas em voz alta. Then, distinguishing the external character of these voices, we seek to identify elements for the perception and analysis of the voice that manifests itself in Cabral's poetry as virtuality, consisting of sound materiality and poetic subjectivity. We do this with

1 Instituto Federal de Goiás (IFG)/Universidade Federal de Goiás (UFG), Goiânia, Goiás, Brasil. E-mail: olliver. rosa@ifg.edu.br. 
poems from the book Museu de tudo. In conclusion, we note that the communicative character of Cabral's poem finds broader fields of action when it is moved to the performative scope of vocalization.

Keywords: João Cabral de Melo Neto; Poetry Vocalization; Museu de tudo. 
uando um estudo anuncia ter como objeto a voz ou as vozes na obra de João Cabral de Melo Neto, pode-se esperar dele, com boa possibilidade de acerto, uma análise de, por exemplo, Morte e vida severina, Rio e Dois parlamentos, três dentre as publicações que foram reunidas no livro Morte e vida severina e outros poemas em voz alta. Essa compreensão se deve, em parte, à organização da primeira grande coletânea de Cabral, que dividiu sua poesia em Duas águas. Nas orelhas deste livro, publicado em 1956, está explicada a divisão:

de um lado, poemas para serem lidos em silêncio, numa comunicação a dois, poemas cujo aprofundamento temático quase sempre concentrado exige, mais do que leitura, releitura; de outro lado, poemas para auditório, numa comunicação múltipla, poemas que, menos que lidos, podem ser ouvidos. (DUAS..., 2007, p. LII).

Essa dicotomia se tornou comum nos discursos críticos sobre a poesia cabralina. Leitores especializados, mesmo aqueles que deram outras nuances à distinção, a reforçaram em suas análises. Haroldo de Campos (1992, p. 85), 
O. M. RosA As vozes de dentro da poesia cabralina por exemplo, dispõe assim a dualidade em uma conferência de 1963: "Poesia crítica e poesia que põe o seu instrumento, passado pelo crivo dessa crítica, a serviço da comunidade". Décadas depois, no prefácio à poesia completa do poeta, Antonio Carlos Secchin (2007, p. XIV) afirma: "Quase toda a obra de João Cabral, com certas infiltrações recíprocas, poderia ser distribuída entre poemas dessas duas águas, a da comunicação imediata ou a da leitura reflexiva". Pesquisas como a de Waltencir de Oliveira (2008) demonstram que esse modo de compreensão não se aplica com efetividade a toda a produção de Cabral, sobretudo se considerarmos Museu de tudo e os livros posteriores. A oposição ou separação em duas vertentes deixa de funcionar bem quando verificamos que a obra, a depender do critério com que é observada, pode ser pintada como um quadro diverso.

Se buscarmos dimensionar o caráter comunicativo da poesia de Cabral, essa revisão acontece. Pensando na diferenciação em duas águas, podemos ressalvar que a leitura do poema em silêncio não exclui a percepção do trabalho vocal que está em seu cerne, a qual favorece ou completa a experiência com a poesia. Nesse sentido, todo poema, qualquer seja sua configuração, pode ser ouvido. A multiplicidade da comunicação poética não se define apenas no modo como este ou aquele texto é composto, mas também, e com importância, no modo como ele é recebido e apreciado. É preciso considerar ainda que a vocalização constitui, mais que um modo de recepção, um mecanismo de compreensão dos poemas, tanto os de "comunicação imediata" quanto os destinados para a (re)leitura individual. Cabe aqui um reparo: esquece-se de que a execução vocal de um texto, especialmente de um texto poético, pressupõe, se não exige, uma leitura precedente, que se realize com cuidado e atenção, já que "o próprio ato de pronunciar as palavras obriga-o [o leitor] a entendê-las melhor" (ADLER; VAN DOREN, 1974, p. 220). Desse modo, é simplificador definir poesia comunicativa como aquela que facilita o acesso aos sentidos, produzindo uma determinada melodia por meio de efeitos sonoros e rítmicos, ou aquela que privilegia a marcação clara de uma ou mais vozes.

Além disso, se não é um engano, pelo menos é um pré-conceito pretender que a escuta de uma performance vocal de poesia proporciona apenas uma percepção da pauta rítmica, das recorrências sonoras ou de uma carga melódica, ou que tem efeito apenas quando realizada com poemas que explicitam o diálogo, posto por sua própria composição ou pela escolha de temas de apelo soci al. Com esse entendimento do potencial da comunicação poética, vincula-se, no caso de Cabral, a afirmação, repetida pelo próprio poeta, de que sua poesia recusa a musicalidade. Em entrevista publicada nos Cadernos de Literatura Brasileira do Instituto Moreira Salles, ele diz, por exemplo: "Eu poderia falar que minha poesia é limitada do ponto de vista musical [...]. Todo mundo sabe que eu sou o antimusical por excelência. Por isso evito fazer uma poesia cantante. Não é sequer uma poesia de oratória”
Revista Letras, Curitiba, UFPR, n. 102 , pp. 8-26, jul./dez. 2020 ISSN 2236-0999 (versão eletrônica) 
(MELO NETO, 1996, p. 24). É preciso reconsiderar essa qualificação da poesia cabralina, tendo em vista uma concepção outra do modo como se manifesta no texto poético o elemento musical ou vocal. Eduardo Sterzi (2012, p. 166) nos indica o caminho:

É, pois, como uma cicatriz de sua mais remota pré-história que a lírica continua a trazer a música em si ao menos como virtualidade; por mais obstinada que seja sua emancipação da música e da voz, por mais que se dirija a um estado de pura escrita, conserva sempre uma nostalgia da música e da voz, e em certa medida até do gesto que a vinculava à dança. ${ }^{2}$

Essa relação subterrânea se insinua de modo direto na tematização de elementos da música e da dança, feita em Cabral com imagens do bailar e do cante andaluzes ${ }^{3}$. Por mais que não exista na poesia cabralina uma música evidente ou um discurso eloquente, nela se pronuncia uma voz, que surge de forma silenciosa, ou melhor, silenciada pela preponderância do registro escrito. A vocalização serve justamente para reavivar essa voz em sua potencialidade sonora, deslocando o poema da página para um plano de comunicação ostensiva, no qual o tecido do texto poético se torna partitura vocal. Nos livros ditos para a voz alta, isso acontece de forma mais evidente, mais declarada que em outras produções de Cabral. Para verificar essa diferença - que no fim encontra medida de semelhança -, trazemos à baila dois livros do poeta: a referida coletânea, Morte e vida severina e outros poemas em voz alta, de 1966, e Museu de tudo, de 1975. Aproximamos as duas publicações para verificar de que modo o potencial de sentido da poesia pode ser multiplicado pela execução vocal. Para isso, levamos em conta que, em cada uma dessas obras, a efetivação desse aspecto adquire feições diferenciadas.

O volume Morte e vida severina e outros poemas em voz alta reúne poemas que sugerem textualmente a presença de uma voz. Uma nota que antecede o conteúdo do livro nos oferece material para reflexão:

Este livro, de poemas que talvez funcionem em voz alta (para a
meia-atenção ou quarta parte de atenção que, em geral, é quanto
pode receber o poema que se ouve), contém: um auto (Morte e
vida severina), um monólogo (O Rio), dois poemas que, ao se-
rem publicados, o autor apelidou "parlamentos", e outros poemas
menores que, com esses dois, por implicarem mais de uma voz,
parecem, senão pedir, ao menos suportar uma leitura a vozes e,

2 Utilizamos lírica como sinônimo de poesia. Embora conheçamos a problemática para definição do termo, extrapolaria o escopo deste trabalho discuti-la.

3 Vale conferir, nesse sentido, o artigo de Everton Barbosa Correia (2007), "A musicalidade flamenca de João Cabral", publicado na revista Texto Poético. 
O. M. RosA

As vozes de dentro da poesia cabralina

A possibilidade de funcionamento em voz alta é associada à manifestação de uma ou mais vozes implicadas na própria composição dos poemas antologizados. Em O Rio, realiza-se em monólogo uma espécie de autobiografia. Seu discurso, altamente descritivo, confere dimensão pessoalizada a características geográficas e referências históricas. Em um ritmo quase prosaico, põe-se a voz do rio em relato sobre sua jornada da nascente ao encontro com o mar. Morte e vida severina se apresenta como um auto de natal. Nele falam diferentes personagens que surgem no percurso do retirante Severino: homens e mulheres marcados pelo signo da morte. Embora de certa forma se mantenham indistintas por estarem todas submetidas à indiferença de um mesmo destino, suas vozes se diferenciam e são identificadas textualmente. Em Dois parlamentos, aparecem dois poemas, cuja composição falada/dialogada está indiciada pelos subtítulos e ainda pelo uso do travessão. Em "Congresso no polígono das secas”, reúnem-se várias vozes que se pronunciam com "sotaque sulista" em "ritmo senador" sobre o domínio da morte nos cemitérios gerais. Em "Festa na casa grande", dispõemse diferentes falas com "ritmo deputado e sotaque nordestino" sobre o cassaco de engenho. Os outros poemas ("Velório de um comendador", "O relógio", "Generaciones y Semblanzas", “O motorneiro de Caxangá”, "Sevilha” e "Jogos frutais") chamados no livro de bailes, são separados em partes; a cada uma delas, parece que de fato se manifestam vozes diversas.

As vozes desses poemas, muitas vezes, podem ser facialmente situadas num espaço e tempo, sobretudo se considerarmos, como faz Secchin (1999, p. 180), que aquilo "que se fala não é imune ao lugar de onde se fala". Ouvimos, de uma parte, o Capibaribe personificado dizendo a história de seu curso que segue do sertão a Recife, e a voz esquálida do retirante e de seus pares no domínio senhoreado pela morte; de outra parte, a palavra do outro (absoluto, em uma perspectiva sulista, à distância geográfica, política e econômica, e relativo, do ponto de vista da casa grande, apartado pela desigualdade social) sobre a figura do pobre e sua realidade, posta por uma visada irônica diante da ideologia dominante. Todas essas vozes, sejam marginais, de resistência ou hegemônicas, reclamam de alguma forma a possibilidade de serem ouvidas.

Parece, portanto, que as composições de Cabral destinadas para a voz alta são assim qualificadas especialmente porque nelas está prevista uma participação vocal. Seus versos se propõem a uma comunicação múltipla, que, "a serviço da comunidade", ampliaria os efeitos de sentido. Não podemos, por certo, desconsiderar que os mecanismos de construção dessas composições são diversos dos daquelas que são incluídas na vertente da poesia crítica ou reflexiva. Essa ressalva, no entanto, perde parte de sua aplicabilidade, quando pensamos que a cada poema os procedimentos criativos assumem uma 
disposição particular, ainda que não totalmente nova. Desse modo, mesmo em poemas que parecem não pedir nem suportar uma "leitura a vozes" por conta de seu "aprofundamento temático quase sempre concentrado", entoa-se uma antimelodia que, movida pela intenção de negar uma espécie de musicalidade, cria uma sonoridade própria. Configura-se uma virtualidade vocal, uma voz que, apesar de não identificada, se materializa nos versos. Essa voz se difere daquelas que, como vozes de fora, para usar uma expressão de Secchin (1999), adquirem expressão, sobretudo, pelo que mantém de contato com determinado contexto social. Escutar as vozes de dentro envolve uma escolha diversa, principalmente se esta tiver a vocalização como instrumento em prol da compreensão (uma comunicação mais elaborada) do texto poético. Não se trata de ponderar quanta atenção recebe o poema que se ouve, mas quanta atenção demanda o ato de ouvir de fato o poema que se recebe. Para observar com produtividade essa dimensão, escolhemos Museu de tudo, que ocupa uma posição de destaque na cronologia da poesia cabralina, inaugurando um momento de ampliação de sua identidade.

Essa análise poderia ser feita com outras publicações do poeta, inclusive com as que obedecem a um plano fechado de composição. Perante Educação pela pedra, por exemplo, se tornaria ainda mais significativa, por meio da reflexão sobre o elemento vocal, a ausência de marcação do "eu" e o intercâmbio de versos entre poemas quase equivalentes - entenderemos adiante em que medida pode se processar essa significação. Embora Museu de tudo não tenha a mesma coesão desse e de outros livros de Cabral, que de alguma forma o distinguem, sua variedade temática e formal insinua um projeto criativo pelo avesso. Nesse museu, estão presentes não somente questões que sempre foram caras ao poeta, como também escolhas técnicas que recorrem em sua obra. Constitui-se, aos olhos do leitor, uma espécie de portfólio da poesia cabralina. O propósito de estruturação se estabelece não no conjunto, mas nos poemas individualmente. Essa pluralidade nos interessa, porque, diante dela, podemos verificar de que modo se comportam, numa performance vocal, as vozes de dentro da poesia de João Cabral.

Vamos considerar, primeiramente, alguns aspectos formais, que são constitutivos da vocalidade poética, a saber: a sonorização das rimas; a relação entre as pausas métricas e as pausas semântica e sintática e, decorrente dela, a significação do silêncio imposto pelos enjambements; e, por fim, a identidade ou a diversidade rítmica produzida por ou em relação com as escolhas métricas. Depois, trataremos de elementos que poderíamos chamar de produtivos, pois, embora também configurem de antemão a voz do poema, adquirem efetivo funcionamento com a performance do leitor-vocalizador.

Dentre as figuras de som recorrentes na poesia, a que mais chama atenção é certamente a rima. Para o senso comum, a coincidência fonética em fins de verso se mostra muitas vezes como uma das condições para que 
O. M. RosA As vozes de dentro da poesia cabralina um texto seja considerado poético. Esse entendimento se refere, no entanto, apenas a uma espécie de rima, a consoante, que aparece quando há completa equivalência de sons a partir da última sílaba tônica no final do verso. Essa equivalência se expressa até mesmo no registro escrito, no qual surge a (quase) igualdade entre as letras. Na poesia de Cabral, ocorrem rimas consoantes, mas, sem dúvida, eles não se sobressaem ante a predominância das rimas toantes - que designam os casos de correspondência sonora entre apenas as vogais tônicas das palavras. Com o poema na página, silencioso, ao leitor pode passar despercebida a semelhança instaurada por este último recurso fônico. $\mathrm{Na}$ vocalização, os sons ganham vida, sobrelevando a identidade entre, por exemplo, o "a" tônico de palavras aparentemente distintas na mancha gráfica. Enquanto a rima consoante perfaz a harmonia proporcionada pela repetição de sons, a toante

\begin{abstract}
é menos precisa. Ela satisfaz a nossa expectativa sonora, mas não a satisfaz totalmente, porque os sons não são exatamente iguais. Ela deixa um resíduo de tensão não resolvida, mas o poeta hábil sabe usar essa tensão para produzir, por um efeito cumulativo, a sensação de uma harmonia mais cheia de sutilezas, à medida que os versos vão se superpondo uns aos outros. (TAVARES, 2005, p. 41).
\end{abstract}

Isso é certamente o que produz uma sonoridade diversa na poesia cabralina, marcada por força dissonante. Poderíamos até mesmo sugerir que a prevalência de rimas toantes, gerando uma espécie de interferência que cinde a homofonia, articula-se perfeitamente com a carga crítica que permeia os poemas do poeta, seja na reflexão sobre o próprio trabalho da arte, seja no questionamento irônico do quadro social do Nordeste. Vemos, portanto, que Cabral, tantas vezes chamado de antimusical, é, na verdade, um compositor de acordes mais sutis. A qualidade sonora de sua criação se enriquece ainda em trechos em que se alternam rimas toantes e consoantes, como no poema "Paráfrase de Reverdy":

$$
\begin{aligned}
& \text { O prosador tenta evitar } \\
& \text { a quem o percorre esses trancos } \\
& \text { da dicção da frase de pedras: } \\
& \text { escreve-a em trilhos, alisando-a } \\
& \text { até o deslizante decassílabo } \\
& \text { discursivo do chão de asfalto } \\
& \text { que se viaja em quase-sono, } \\
& \text { sem a lucidez dos sobressaltos. }
\end{aligned}
$$$$
\text { (MELO NETO, 2007, p. 372). }
$$

Revista Letras, Curitiba, UFPR, n. 102 , pp. $8-26$, jul./dez. 2020 ISSN 2236-0999 (versão eletrônica) 
$\mathrm{Na}$ primeira estrofe, rimam em toante as palavras "trancos" e "alisando", o que provoca uma espécie de desentoação, algo sugestivo quando associado à imagem áspera de uma "dicção da frase de pedras". Já na segunda estrofe, aparecem consoantes "asfalto" e "sobressaltos", que fazem o som fluir como um "deslizante decassílabo discursivo". O emprego dessa tensão rímica é expediente comum em toda a poesia de Cabral, o qual se torna chave de percepção na e para a vivência vocal.

A vocalização favorece ainda a constatação de que, na obra cabralina, a sintaxe de seu verso não interfere tão drasticamente na sintaxe da língua, visto que não são tão frequentes inversões e rupturas na linearidade das sentenças. Os fins de verso coincidem muitas vezes com o limite de um termo da oração (sujeito, predicado, objetos e adjuntos adverbiais), se harmonizando com as unidades gramaticais. É comum que a pausa métrica reforce pausas semânticas e sintáticas, contribuindo para isso a predominância de construções paratáticas. ${ }^{4}$ Uma poesia que não é dada a inúmeros e insólitos torneios sintáticos com certeza impõe menos dificuldades a sua execução vocal. De qualquer forma, esta se mostra mais produtiva quando, a princípio, como etapa de preparação, ressalta os fins de verso e a separação das estrofes, ainda que depois se opte pela vocalização cursiva do poema. É preciso externar essas divisões não para enclausurar a vocalização nos limites do verso, mas para perceber com mais clareza (talvez a melhor palavra fosse concretude) quais são as potencialidades de significação instauradas pela relação entre a gramática do poema e a gramática da língua. O gesto vocal possibilita ao vocalizador constatar qual é o efeito gerado pelas pausas incomuns à fluidez da fala prosaica, chamando atenção para as quebras que são significativas. Leiamos "Os polos do branco (ou do negro)":

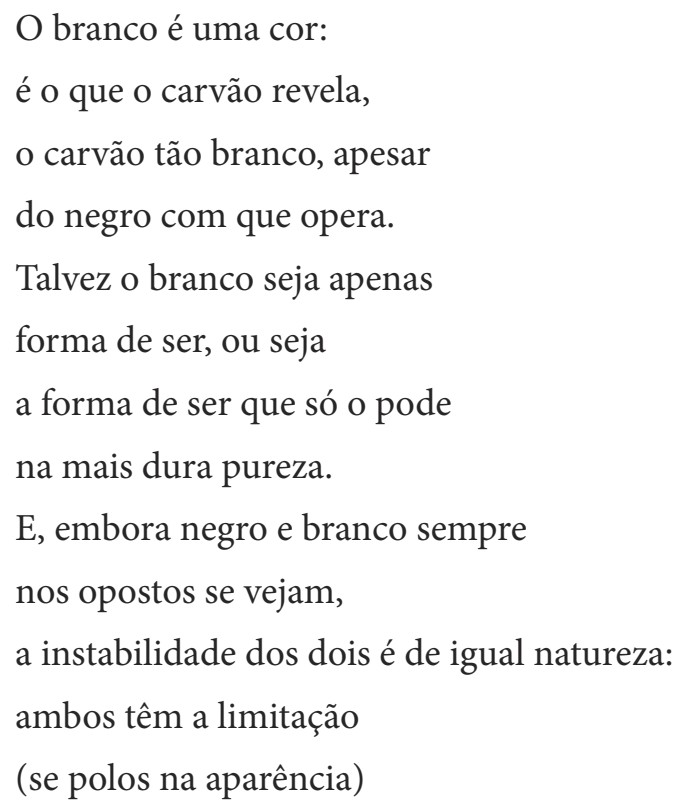

4 Essa característica faz com que em muitos poemas de Cabral seja possível a reordenação de versos sem que se perca a produtividade dos sentidos. A mesma relação paratática se processa entre as partes ou blocos que compõem alguns poemas. 
O. M. RosA

As vozes de dentro da poesia cabralina glandular, de só conseguirem

viver na intransigência.

(MELO NETO, 2007, p. 380-381).

Esse poema chama atenção pela ocorrência marcante do enjambement ou encadeamento sintático em quase toda sua construção. Se respeitar as pausas métricas, o vocalizador poderá aferir de que maneira o silêncio como ausência sonora representada pelo espaço em branco pode pluralizar os sentidos. Chamam atenção, nesse aspecto, estes versos, com grifos nossos: "O branco é uma cor:", “Talvez o branco seja apenas" e "forma de ser, ou seja”. Todos eles ficam momentaneamente abertos por serem interrompidos pela quebra da linha, a qual, instaurando um vazio, se ajusta bem com o gesto de dizer o que é o branco. A dificuldade imposta por esses versos a uma execução vocal fiel ao metro contribui sem dúvida para que essas sutilezas sejam mais facilmente notadas. $\mathrm{O}$ mesmo pode ser dito a respeito da pontuação, que na performance se transforma em diferentes durações. Quando se deparar, por exemplo, com parênteses, o vocalizador terá de encontrar uma forma para expressar vocalmente a presença desses sinais gráficos, o que o obriga a ponderar a participação deles na produtividade semântica do poema. Assim, em "Os polos do branco (ou do negro)" se tornará corporalmente significativa a complementaridade entre a interrupção imposta pela ressalva "se polos na aparência" e a palavra "limitação", apartada de seu determinante, o adjetivo "glandular". Percebidas essas nuances todas, pode-se partir para a observação do funcionamento sonoro do poema como um todo, visto que o verso só adquire ritmo (que é sonoro e semântico) no conjunto que integra.

O ritmo designa na poesia a alternância de sílabas dotadas de uma energia diversa, qualificando-se, na performance, em andamento e entoação. $\mathrm{O}$ andamento diz respeito ao tempo e à velocidade e a entoação se refere à modulação da linha melódica conforme uma intencionalidade específica. São essas modalidades que se tornam evidentes quando o verso é investido pela realidade de uma voz. No texto poético em suporte escrito, vemos apenas rastros. O impulso rítmico se apresenta com sua totalidade somente quando o poema é realizado (ou pensado) sonoramente. Dessa maneira, um verso destacado de seu contexto, mesmo que escandido, diz muito pouco ou nada da pauta rítmica de que ele faz parte. "Não podemos compreender o ritmo a partir da linha do verso; ao contrário, compreender-se-á o verso a partir do movimento rítmico" (BRIK, 1971, p. 132). A escolha métrica apenas participa como elemento de intervenção externa da constituição da cadência rítmica, que se sobreleva como força interna da poesia, sobretudo quando esta é objeto de vocalização; a distribuição em sílabas poéticas se coloca, assim, como definição exterior à produtividade de sentidos do texto poético. A relação entre dois poemas pode tornar essa explicação mais clara: 
Retrato de andaluza

\begin{abstract}
Estatura pequena e nítida
das cidades de onde ela era

daquele justo para o abraço

que é de Cádiz, onde nascera,

e de Sevilha, onde vivia

e se dizia, mas não era:

cidades que ainda se podem

abraçar de uma vez, completas,

e que dão certo estar-se dentro,

àquele que as habita ou versa,

a entrega inteira, feminina,

e sensual ou sexual, de sesta.
\end{abstract}

(MELO NETO, 2007, p. 358).

Outro retrato de andaluza

Clareza para vários sentidos,

e de luz, mas sem transparência:

não clareza de um copo de água,

mas interna, carnal, espessa.

Clareza não só para a vista:

clareza ao dente do pão fresco,

do riso claro à vista e ao ouvido,

ao tato, de coxa ou de seio.

Clareza do ar que sempre acende,

do ar de sal vivo que conversa,

do ar fêmea que toda a envolve,

ar tangillo das saias dela.

(MELO NETO, 2007, p. 379-380).

No primeiro, todos os versos são octossílabos; no segundo, apenas o primeiro verso não tem oito sílabas. Esse metro dificulta a fluidez dos versos - certamente, não tem a mesma leveza de uma redondilha -, mas, nesse caso, a presença marcante de sílabas longas produzidas por sinalefa (crase, elisão e sinérese) proporciona uma sensação de envolvimento que compensa essa limitação. Vê-se que a proximidade temática entre os dois poemas está plasmada também no aspecto formal. Embora o segundo conduza a um ritmo mais variado, conforme a posição das tônicas, em ambos a pauta rítmica se harmoniza bem com as imagens para as quais se encaminham os versos: "a 
O. M. RosA As vozes de dentro da poesia cabralina entrega inteira, feminina,/ e sensual e sexual, de sesta" e "do ar fêmea que toda a envolve, ar tanguillo das saias dela”. Diferencia-se, no entanto, sua disposição estrófica. O primeiro se constitui em apenas um bloco de versos - escolha bem articulada com a ideia do abraço, do "estar-se dentro", central no poema -, ao passo que o segundo se divide em três estrofes, marcadas pelo espaço em branco, que leva à pausa e ao silêncio - o que plasma na carne do poema a imagem interna da clareza, palavra que, repetida cinco vezes em doze versos, propulsa os sentidos. A primeira andaluza é retratada sob uma tonalidade menos rígida, até mesmo mais espontânea, do que a segunda. O ritmo se transforma ao ganhar corpo de uma voz, ao se produzir junto ${ }^{5}$ desse corpo.

Cada poema surge com um compasso rítmico que lhe é próprio. As escolhas de que é resultado estão subordinadas a determinados movimentos "que nascem na linguagem do corpo, na dança dos sons, nas modulações da fala" (BOSI, 2000, p. 103). Em Museu de tudo, encontramos versos de diferentes medidas (de dissílabos a bárbaros) e organizações métricas (isometria, heterometria, versificação livre), uma diversidade que se amplia ainda mais com a produção de sentidos por meio do ritmo e de suas qualificações: em poemas, por exemplo, de seis sílabas, tão numerosos nesse livro, esse metro ganha a cada vez um novo tratamento sonoro. Noutra ocorrência, um mesmo tema pode ganhar diferentes versões formais, é o que pode ser percebido, por exemplo, quando ouvimos a execução vocal de "El cante hondo" (quase todo em octossílabos) e "Ainda el cante flamenco" (todo em redondilhas).

A hesitação entre som e sentido, para pensarmos como Paul Valéry (1991), se processa em toda poesia. Como diz o poeta e crítico francês: "O pêndulo vivo que desceu do som em direção ao sentido tende a subir de novo para o seu ponto de partida sensível" (VALÉRY, 1991, p. 213). Mesmo que não seja simétrico, esse movimento pendular se instaura em qualquer poema, de modo que por ele se expressam não apenas as relações sonoras, a que as semelhanças produzidas pelo trabalho com o significante dão evidência, mas também os elementos que se articulam no interior do texto poético para a produção de sentidos. A experiência sensível tem relação com os mecanismos materiais necessários para que se proceda à significação. Nesse sentido, a materialidade sonora própria de uma dicção dá som à voz, configurada no poema por meio do repertório imagético de uma dada subjetividade, que se pronuncia explicitamente ou não. A vocalização exterioriza uma condição enunciativa, realizando-a, e, assim, manifesta a existência do texto poético no presente, dando-lhe concretude sonora em certo período de tempo e num determinado espaço. Essa relação espaço-temporal não se conforma de modo simples, quando o corpo do leitor encontra o corpo do poema e se une a ele. Afinal, nesse contato (e contrato) de subjetividades, a voz leitora dá a

Revista Letras, Curitiba, UFPR, n. 102 , pp. $8-26$, jul./dez. 2020 ISSN 2236-0999

5 Pensamos na etimologia da palavra sensual, como aquilo que é relativo aos sentidos, dos sentidos, relativo às sensações. 
conhecer a voz poética e, ao mesmo tempo, oferece à audição sua própria particularidade fônica.

$\mathrm{Na}$ execução vocal, conhecemos de uma forma mais contundente a relação que a voz pronunciada no poema estabelece com o tempo e o espaço. As referências a lugares deixam de ser, pelo menos momentaneamente, registros textuais que podem ou não ressoar no repertório do leitor, para se tornar indicadores de uma localização que se distancia ou se aproxima do aqui da performance. As marcações temporais nos verbos adquirem uma aparente efetividade cronológica quando tomadas por um corpo com realidade no presente. Vejamos, por exemplo, "A Quevedo":

\author{
Hoje que o engenho não tem praça, \\ que a poesia se quer mais que arte \\ e se denega a parte \\ do engenho em sua traça, \\ nos mostra teu travejamento \\ que é possível abolir o lance, \\ o que é acaso, chance, \\ mais: que o fazer é engenho. \\ (MELO NETO, 2007, p. 368).
}

No poema, "hoje" equivale a "atualmente". Essa temporalidade solicita ao leitor-vocalizador uma reflexão sobre a vigência do que é dito no poema: será que, no contexto presente, a poesia de fato "se denega a parte do engenho em sua traça"? Além disso, a voz do poema já no título instaura um endereçamento. A remissão a Quevedo gera uma aproximação com uma determinada enciclopédia de leitura, uma aproximação que adquire a expressão de um diálogo efetivo. $\mathrm{O}$ gesto de endereçar algo a alguém estabelece de antemão uma interlocução, a qual se completa com o pedido: que Quevedo nos mostre "teu travejamento", revelando "que o fazer é engenho". Há nessa referência um jogo irônico, que critica por meio de sutil negação a poesia produzida sem um "trabalho de arte". Ao compartilhar com o vocalizador um movimento de ironia, o poema se refaz como uma metaironia, que, como diz Paz (1984, p. 142), "não se interessa pelo valor dos objetos, mas sim pelo seu funcionamento". No ato vocal, esse viés irônico é transformado num andamento e numa entoação, o que é apenas sentido possível se torna sentido realizado. Essa intervenção não pode acontecer sem uma leitura prévia, preocupada não apenas com a significação do poema, mas com a exteriorização desta em performance. Desse modo, a alusão ao escritor espanhol, presentificada pelo uso do "hoje", perfomatizada pelo gesto do endereçamento e do pedido e clivada pelo caráter inclusivo do pronome "nos", adquire uma dimensão outra de significação. 
O. M. RosA As vozes de dentro da poesia cabralina

Nesse sentido, o processo de leitura palimpséstica do qual surge o poema moderno, como afirma João Alexandre Barbosa (1986, p. 15), se transforma em eco na vocalização. A leitura da tradição ganha corpo na leitura do leitor, que "deixa de ser o consumidor para se incluir como latência de uma linguagem possível" (BARBOSA, 1986, p. 14). Se no ato de ler o poema já é colocado em contato com aspectos culturais que são exteriores e, muitas vezes, posteriores a ele, no ato de vocalizar, ele é posto em congregação efetiva ora conflituosa ora confluente. Ao executar vocalmente a partitura poética, o indivíduo declara sua (a própria e a do poema) condição histórica, revelando vocalmente o diálogo que prolonga a consciência de leitura pela qual se fez o texto poético. O leitor, de alguma forma, reinscreve o poema ao situá-lo num espaço (aqui) e num tempo (o agora). O poema "Acompanhando Max Bense em sua visita a Brasília, 1961” (MELO NETO, 1997, p. 43-44) apresenta indicações de uma circunstância:

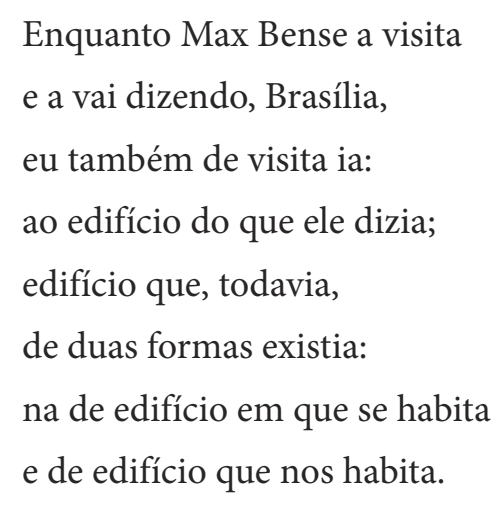

A circunstância perde, no entanto, sua carga de contingência para atingir o campo do universal. Na vocalização, o tempo da memória se transforma, pois é submetido a uma espécie de atualização. Isso favorece a percepção e o entendimento de que os eventos ali mencionados não dependem diretamente do que se passou na realidade e não requerem uma verdade empírica para significar. Embora existam uma pessoa chamada Max Bense e uma cidade chamada Brasília, o conhecimento disso contribui para a significação do poema menos pelo que são essa pessoa e essa cidade do que pelo que elas passam a ser no texto. A simulação, instalada pelo processo representativo, denuncia-se na medida em que o vocalizador pode dar corpo ao "eu" que se pronuncia, sem que isso implique prejuízo para o sentido do poema ou para a identidade do indivíduo. Afinal, durante a performance, há uma coincidência momentânea: a voz física fala junto com a voz poética.

Este último comentário aponta para um aspecto decisivo, talvez o mais importante, da condição que se afirma com a performance vocal de poesia. Trata-se do encontro, que logo se torna jogo, entre a subjetividade configurada nos poemas e a subjetividade do indivíduo que procede à leitura e, como ato associado, à vocalização. Ao longo de todo o artigo, falamos em 
manifestação de uma voz (ou vozes), isso por duas razões: a primeira, já discutida, a intenção de realçar a constituição sonora do poema, que adquire uma sonoridade, um timbre peculiar; a segunda, a compreensão de que:

Longe de exprimir-se como um sujeito já constituído que o po-
ema representaria ou exprimiria, o sujeito lírico está em perma-
nente constituição, em uma gênese constantemente renovada
pelo poema, fora do qual ele não existe. O sujeito lírico se cria no
e pelo poema, que tem valor performativo. (COMBE, 2009-2010,
p. 128).

Tendo em vista esse valor performativo, não é difícil admitir que as variadas configurações do sujeito que fala no poema resultem em efeitos diversos no ato da vocalização. Um poema em que aparece marcada textualmente a pessoa gramatical e outro em que essa marcação se ausenta não criarão a mesma relação com o leitor-vocalizador. Quando este executa vocalmente, por exemplo, o verso "eu também de visita ia", dá corpo a uma vocalidade que diz e se diz, passando a se identificar com ela. $\mathrm{O}$ "eu”, que ocupa ali posição central, não pode ser ignorado como propulsor de sentido, de modo que se estabelece uma espécie de contrato entre a subjetividade constituída no e pelo poema e a subjetividade expressa pela própria voz em performance.

Há aqueles poemas que instalam essa relação por meio da interlocução sugerida ou declarada. Em "A Quevedo", vimos justamente como o gesto do endereçamento e do pedido e o uso inclusivo do pronome "nos" estabelece, no ato vocal, um espaço de interação. Em "W.H. Auden”, é a referência ao "tu" que modifica o jogo subjetivo posto em cena, aproximando emissor e interlocutor por meio da fala que tem lugar no poema: "Mas ela certo te respeitava,/ de muito ler reler teus livros,/ pois matou-te com a guilhotina, fuzil limpo, do ataque cardíaco." (MELO NETO, 2007, p. 356, grifos nossos). Isso pode se expressar de maneira mais sutil, como, por exemplo, no pequeno poema "Saudades de Berna":

\footnotetext{
Onde jamais reencontrar

a submissa ambiência suíça?

onde outra vez reencontrar

a insuíça voz insubmissa?

(MELO NETO, 2007, p. 378).
}

Apesar de não existir nesse poema indicação explícita de um sujeito, sua presença está indiciada: primeiro, pela afetividade implicada no título; segundo, pela formulação de versos-pergunta. A performance assumirá tanto a relação afetiva criada pela referência a Berna, um lugar bem específico, unida à expressão de um sentimento, as saudades, quanto o gesto de interpelação 
O. M. RosA As vozes de dentro da poesia cabralina de um outro possível. Ao aderir sua voz ao poema, o vocalizador não poderá simplesmente executá-lo sonoramente, é preciso que suas escolhas partam de uma interpretação bem pontuada. Afinal, como dissemos, sentidos que estão apenas sugeridos, quando vocalizados, atingem um plano de significação mais efetivo. No exemplo, não poderá passar despercebido o ponto irônico instalado pela negação da afetividade que foi anunciada no título. Para isso, requer-se do leitor um conhecimento extratextual: Berna é a capital da Suíça. O tom da indagação não é saudoso; se fosse, a voz do poema não utilizaria nem o advérbio "jamais" nem o prefixo in-, que, em lugar de certificar o desejo de reencontro, aponta para o anseio de distanciamento. Esse é o subtexto da partitura vocal.

Ao dar realidade a determinado ritmo, que se qualifica em um andamento e em uma entoação, a modulação vocal é responsável, como se pode admitir, por caracterizar sonoramente a atmosfera projetada pelo poema. Essa interferência se torna ainda mais significativa quando na malha textual inexiste uma marcação explícita da presença da subjetividade. Em Museu de tudo, os diferentes e muitos retratos feitos por Cabral se enquadram nessa condição. A configuração subjetiva não se instaura pela manifestação do "eu" ou pela relação enunciativa com o outro, mas pelo estabelecimento de uma perspectiva. Quando incorpora um desses poemas, o vocalizador assume sua posição enunciativa, que coloca em foco aspectos de um objeto, uma pessoa ou um evento, conforme determinado repertório de mundo. É um exemplo "O pernambucano Manuel Bandeira":

\author{
Recifense criado no Rio, \\ não pôde lavar-se um resíduo: \\ não o do sotaque, pois falava \\ num carioca federativo. \\ Mas certo sotaque do ser, \\ acre mas não espinhadiço, \\ que não pôde desaprender \\ nem com sulistas nem no exílio.
}

(MELO NETO, 2007, p. 358).

De início, já se afirma uma escolha: Manuel Bandeira. Os elementos eleitos para sua qualificação dizem respeito a determinado modo de apreensão da realidade. Afinal, deu-se destaque à naturalidade do indivíduo, remeteuse a sua biografia e revelou-se certo conhecimento íntimo do pernambucano Manuel. Essa indeterminação da voz do poema se desfaz de algum modo quando este é levado à performance, na medida em que todas as relações ali dispostas passam, momentaneamente, a ter uma existência concreta. Essa
Revista Letras, Curitiba, UFPR, n. 102 , pp. $8-26$, jul./dez. 2020 ISSN 2236-0999 (versão eletrônica) 
experiência de identidade e proximidade com o que é dito no texto poético tem grande poder de (re)conhecimento para o leitor-vocalizador.

É a consciência de todos esses aspectos que possibilita ao leitor mergulhar em quaisquer águas, profundas ou rasas. Estar aberto a experienciar a vocalidade manifesta no poema o prepara para que ele mesmo encampe a comunicação poética. Como afirma Zumthor (2007, p. 87): “a leitura do texto poético é escuta de uma voz. O leitor, nessa e por essa escuta, refaz em corpo e em espírito o percurso traçado pela voz do poeta”. A leitura de um poema é, em sua própria constituição, uma espécie de audição. Essa relação se concretiza quando o leitor se torna vocalizador. Uma performance vocal bem realizada será justamente aquela que consegue articular efetivamente a enunciação lírica. Considerar a vocalização de poesia como performance, nesse sentido, é tentar tornar evidente o contato corpóreo por meio do qual se faz a leitura de poemas, constituída, a princípio, por um conhecimento sensível.

Na conferência "Da função moderna da poesia", Cabral demonstra sua preocupação com a necessidade de comunicação com o leitor, que, para ele, seria ignorada pelo poeta moderno. Ele vincula essa falta com a atenção excessiva dada ao processo de expressão individual e à obtenção de recursos formais ajustados a tal fim. Sem deixar de concordar com esse argumento, acreditamos que a perda de leitores para o texto poético se deve em grande medida ao modo como estes o têm recebido, como o próprio poeta aponta na referida conferência em relação ao uso dos novos meios de comunicação. Embora se atribua um caráter ativo e participativo ao leitor, este não poderá atuar com efetividade se não dispuser das ferramentas necessárias para a concretização de seu papel. Zumthor (2007) sugere, nesse sentido, que a perda de público não é uma ameaça à poesia, mas a um modo de lê-la. O autor considera que está em processo uma ressurgência das forças vocais, que vem questionar o império secular da escrita. É preciso, nesse sentido, que o leitor afine seu ouvido para se tornar sensível à voz do outro, presente de forma peculiar no poema, e, assim, à sua própria voz. Desse modo, ele poderá perceber que, na poesia de Cabral, mesmo naqueles momentos em que os caminhos do sentido são pedregosos, ganha corpo uma voz que oferece diferentes formas de diálogo e se abre para uma performance vocal significativa. 
O. M. RosA As vozes de dentro da poesia cabralina

\section{Referências}

ADLER, Mortimer; VANDOREN, Charles. Comoler poesia lírica. In: ADLER, Mortimer; VANDOREN, Charles. A arte de ler. Trad. José Laurentino de Melo. Rio de Janeiro: Agir, 1974. p. 218-223.

BARBOSA, João Alexandre. As ilusões da modernidade. In: BARBOSA, João Alexandre. As ilusões da modernidade. São Paulo: Perspectiva, 1986. p. 13-37.

BOSI, Alfredo. Frase: música e silêncio. In: BOSI, Alfredo. O ser e o tempo da poesia. 6. ed. São Paulo: Companhia das Letras, 2000. p. 77-129.

BRIK, Osip. Ritmo e sintaxe. In: TOLEDO, Dionísio de O. (org.). Trad. Ana Filipouski et al. Teoria da literatura: formalistas russos. Porto Alegre: Globo, 1971. p. 131-139.

CAMPOS, Haroldo de. O geômetra engajado. In: CAMPOS, Haroldo de. Metalinguagem e outras metas. 4. ed. São Paulo: Perspectiva, 1992. p. 77-88.

COMBE, Dominique. A referência desdobrada. Trad. Iside Mesquita e Vagner Camilo. Revista USP, São Paulo, n. 84, p. 112-128, dez.-fev. 2009-2010.

CORREIA, Everton Barbosa. A musicalidade flamenca de João Cabral. Texto Poético, v. 4, 2007. Disponível em: http://textopoetico.emnuvens.com.br/rtp/ article/view/173. Acesso em: 12 ago. 2013.

DUAS águas. In: MELO NETO, João Cabral de. Poesia completa e prosa. 2. ed. Rio de Janeiro: Nova Fronteira, 2007. p. XII.

MELO NETO, João Cabral de. Morte e vida severina e outros poemas em voz alta. 17. ed. Rio de Janeiro: José Olympio, 1982.

MELO NETO, João Cabral de. Entrevista. In: INSTITUTO MOREIRA SALLES. Cadernos de Literatura Brasileira: João Cabral de Melo Neto. Rio de Janeiro: IMS, 1996. v. 1.

MELO NETO, João Cabral de. Da função moderna da poesia. In: MELO NETO, João Cabral de. Poesia completa e prosa. 2. ed. Rio de Janeiro: Nova Fronteira, 2007. p. 733-738.
Revista Letras, Curitiba, UFPR, n. 102 , pp. $8-26$, jul./dez. 2020 ISSN 2236-0999 (versão eletrônica) 
OLIVEIRA, Waltencir de. O gosto dos extremos: tensão e dualidade na poesia de João Cabral de Melo Neto, de Pedra do Sono a Andando Sevilha. 2008. Tese (Doutorado em Teoria Literário e Literatura Comparada) - Faculdade de Filosofia, Letras e Ciências Humanas, Universidade de São Paulo, 2008.

PAZ, Octavio. Os filhos do barro. Trad. Olga Savary. Rio de Janeiro: Nova Fronteira, 1984.

SECCHIN, Antonio Carlos. João Cabral: a poesia do menos e outros ensaios cabralinos. 2. ed. Rio de Janeiro: Topbooks, 1999.

SECCHIN, Antonio Carlos. Prefácio: do fonema ao livro. In: MELO NETO, João Cabral. Poesia completa e prosa. 2. ed. Rio de Janeiro: Nova Fronteira, 2007. p. XV-XXI.

STERZI, Eduardo. Da voz à letra. Alea, Rio de Janeiro, v. 14/2, p. 165-179, jul.-dez. 2012.

TAVARES, Braulio. Contando histórias em versos: poesia e romanceiro popular no Brasil. São Paulo: Ed. 34, 2005.

VALÉRY, Paul. Poesia e pensamento abstrato. In: VALÉRY, Paul. Variedades. São Paulo: Iluminuras, 1991. p. 201-218.

ZUMTHOR, Paul. Performance, recepção, leitura. Trad. Jerusa Pires Ferreira e Suely Fenerich. 2. ed. São Paulo: Cosac Naify, 2007.

Submetido em: 03/03/2020

Aceito em: 30/10/2020 